Lepr Rev (1997) 68, 117-124

\title{
Detection of S-100 protein and anticeramide antibodies in leprosy patients by ELISA
}

\author{
R. NARAYAN*, P. K. MAHESHWARI $\dagger$, \\ K. V. DESIKAN $\ddagger \&$ B. C. HARINATH* $\S$ \\ * Department of Biochemistry \& J. B. Tropical Disease Research \\ Centre, $\dagger$ Division of Skin and VD, Department of Medicine; and \\ $\ddagger$ Leprosy Histopathology Centre, Mahatma Gandhi Institute of \\ Medical Sciences, Sevagram-442 102, India
}

\section{Accepted 11 November 1996}

Summary The status of assay for S-100 antigen protein and anticeramide antibodies in serum in understanding nerve damage in different forms of leprosy were evaluated by the enzyme immunoassay. Based on the clinical and smear examination, patients were classified as indeterminate (Ind), tuberculoid (TT), borderline tuberculoid (BT), borderline lepromatous (BL) and lepromatous (LL).

Antibody levels against ceramide were observed in sera of leprosy patients with $37.5 \%$ of Ind, $28 \%$ of TT, $66 \% \mathrm{BT}, 78 \% \mathrm{BL}$ and $62 \% \mathrm{LL}$ patients positive as against $8 \%$ endemic normal sera. The mean OD ranged from 0.141 to 0.275 in different groups of leprosy. In contrast, S-100 was detected in $71.4 \%$ Ind, $88.8 \%$ TT, $76.4 \%$ BT, $100 \%$ BL and $95.8 \% \mathrm{LL}$, while $5 \%$ of ENL samples were positive for S-100 antigen. Mean S-100 levels in these different categories of patients were significantly higher Ind $-0.45 \mathrm{ng} / \mathrm{ml}, \mathrm{TT}-0.32 \mathrm{ng} / \mathrm{ml}, \mathrm{BT}-0.23 \mathrm{ng} / \mathrm{ml}, \mathrm{BL}-0.23 \mathrm{ng} / \mathrm{ml}, \mathrm{LL}-$ $0.19 \mathrm{ng} / \mathrm{ml}$ as compared to that of normal $0.07 \mathrm{ng} / \mathrm{ml}$.

In general S-100 seems to be a more sensitive and reliable marker than anticeramide antibodies for nerve damage. Five out of 7 indeterminate cases show increased levels of S-100, showing an extent of nerve damage similar to that of TT and could be a useful marker for assessing nerve damage in indeterminate patients for better management.

\section{Introduction}

Leprosy is a granulamatous disease primarily affecting the peripheral nerves. Nerve damage has been observed with varying degrees of involvement in virtually all leprosy patients. The possible role of autoimmune mechanism in the nerve damage has been implicated. ${ }^{1}$ Antibodies against nerve components have been detected in sera of leprosy patients by screening them against different preparations of nerve antigens. ${ }^{2-6}$ Nerve tissue antigens like

Correspondence: § Director-Professor and Head, Department of Biochemistry \& J. B. Tropical Disease Research Centre, MGIMS, Sevagram-442 102, India. 
glycosphingolipids (ceramide, galactocerebroside, gangliosides and sulphatides) present in the nervous tissue are known to be immunogenic. Antibodies to total nerve lipids and galactocerebrosides have been demonstrated in the sera of leprosy patients. ${ }^{7}$ Patients suffering from Gullian-Barré syndrome and systemic lupus erythromatosis with peripheral neuropathy have elevated levels of antiglycosphingolipids. ${ }^{8}$ In an experimental study on Mangaby monkeys, antibodies to ceramide, galactocerebroside and gangliosides have been shown to be increased 15 months prior to clinical evidence of nerve damage. ${ }^{9}$ In a more recent study Vemuri et al. ${ }^{10}$ have detected antibodies to all categories of leprosy patients, with anticeramide antibodies showing higher titres.

A specific nerve tissue protein S-100 protein, (so called because of its solubility in $100 \%$ saturation with ammonium sulphate) has been demonstrated in normal nerves and nerve complexes by immunoperoxidase staining. ${ }^{11}$ Employing the same technique the depletion of S-100 protein in dermal nerves of leprosy patients was shown, suggesting the usefulness of this technique in assessing the presence of nerve damage. ${ }^{12-14}$ In the present study we have estimated levels of S-100 and levels of anticeramide antibodies in the sera of leprosy patients by ELISA.

\section{Materials and methods}

\section{SUBJECTS}

Blood samples were collected from untreated leprosy patients, attending the Skin and VD Outpatient Department of Kasturba Hospital, Sevagram. The patients were classified according to the Ridley-Jopling criteria as indeterminate (Ind), tuberculoid (TT), borderline tuberculoid (BT), borderline lepromatous (BL), lepromatous (LL) cases. Blood samples were also collected from healthy subjects living in this region to be used as negative controls. Sera were separated and stored at $-70^{\circ} \mathrm{C}$ with $0.01 \%$ sodium azide as a preservative.

\section{SERUM SAMPLES}

A total of 92 serum samples belonging to different groups, namely, Ind (7), TT (18), BT (17), BL (6), LL (24) and EN (20) were analysed for the presence of S-100 protein.

In addition to the above sera, 68 serum samples of which Ind (1), TT (7), BT (12), BL (17), LL (26) and EN (5) were also screened for anticeramide antibodies. Hence, a total of 160 samples were screened for anticeramide antibodies.

\section{ANTIGENS AND ANTIBODIES}

S-100a protein (Sigma Chemical Company, USA) and rabbit anti-S-100 protein antibodies (Dako, Denmark) were provided by Lepra, UK. Ceramide (Centre for Biochemical Technology, New Delhi) and antihuman IgM horse radish peroxidase (HRPO) conjugate (Sigma Chemical Co. USA) and antirabbit IgG HRPO conjugate (Cappel, USA) were used in this study.

INHIBITION ELISA FOR DETERMINATION OF S-100 PROTEIN

For the detection of S-100 protein, each serum was saturated $50 \%$ with ammonium sulphate 
and centrifuged. The supernatant was collected and added to EDTA at a final concentration of $1 \mathrm{~mm}$, and then preincubated with $500 \mathrm{ng}$ of rabbit anti-S-100 protein antibodies at $37^{\circ} \mathrm{C}$ for $30 \mathrm{~min}$ and then used for screening by ELISA.

Flat-bottomed PVC microtilre plates (Dynatech, USA) were sensitized with S-100 protein $(0 \cdot 1 \mu \mathrm{g} / 50 \mu \mathrm{l} /$ well $)$ in a $0.06 \mathrm{M}$ carbonate buffer $\mathrm{pH} 9.6\left(37^{\circ} \mathrm{C}\right.$ for $\left.2 \mathrm{hr}\right)$. The wells were further blocked with $3 \%$ bovine serum albumin $100 \mu \mathrm{l} /$ well in the same buffer $\left(37^{\circ} \mathrm{C}\right.$ for $2 \mathrm{hr}$ ) and washed 5 times with phosphate buffer saline $(0.01 \mathrm{M} \mathrm{pH} \mathrm{7.2)} \mathrm{containing} \mathrm{Tween} 200.01 \%$ (PBS/T). Then $50 \mu \mathrm{l}$ of preincubated reaction mixture of sera were added to the wells (as described above), and incubated at $37^{\circ} \mathrm{C}$ for $1 \mathrm{hr}$. After washing with PBS/T the wells were further incubated with optimally diluted $(1: 8000)$ antirabbit $\operatorname{IgG} \mathrm{HRPO}$ conjugate at $37^{\circ} \mathrm{C}$ for $1 \mathrm{hr}$. Following, the final washing, the immune reaction was revealed by incubating with orthophenylene diamine (OPD) substrate consisting of $5 \mathrm{mg}$ OPD, $5 \mathrm{ml}$ citrate phosphate buffer $\mathrm{pH} 5 \cdot 0$, and $5 \mu \mathrm{l}$ of $30 \% \mathrm{H}_{2} \mathrm{O}_{2}$. The enzyme substrate reaction was then terminated by addition of $2 \mathrm{~N} \mathrm{HCl} 50 \mu \mathrm{l} /$ well and the absorbance was read at $490 \mathrm{~nm}$ using ELISA reader (Dynatech, MR-250 USA). The optical density values were interpreted in a dose response curve to obtain S-100 protein level in $\mathrm{ng} / \mathrm{ml}$. The dose response curve was prepared by using varying concentrations $(0.4$ to $2.5 \mathrm{ng} / \mathrm{ml})$ of S-100 protein in pooled normal serum.

\section{DETECTION OF ANTICERAMIDE IgM ANTIBODY}

Indirect ELISA was performed as described by Vemuri et al. ${ }^{7}$ Briefly, PVC microtitre plates were coated with ceramide in methanol $(2 \mu \mathrm{g} / \mathrm{ml})$ overnight until completely evaporated and blocked with $3 \%$ BSA in phosphate buffered saline (PBS $0.01 \mathrm{~m} \mathrm{pH} \mathrm{7.2)} \mathrm{at} 37^{\circ} \mathrm{C}$ for $2 \mathrm{hr}$. After 2 washes with PBS, the plates were incubated with sera ( $1: 100$ in PBS/2.5\% NRS) at $37^{\circ}$ for $2 \mathrm{hr}$. After 3 washes with PBS the plate was incubated with antihuman IgM HRPO $(1: 2500)$ at $37^{\circ} \mathrm{C}$ for $2 \mathrm{hr}$. This was followed by 3 washes in PBS. The immune reaction was observed by incubating the wells with OPD substrate and the results evaluated after blocking the reaction using $2 \mathrm{~N} \mathrm{HCl}$ at $490 \mathrm{~nm}$.

\section{STATISTICAL ANALYSIS}

Student's $t$ test was used to compare the means of the results obtained in various groups of sera.

\section{Results}

The nerve marker S-100 protein content has been estimated in a total of 92 sera by inhibition ELISA. Figure 1 shows the calibration curve obtained using pooled normal serum quenched with standard S-100 protein $(0.4$ to $2.5 \mathrm{ng} / \mathrm{ml})$. The mean $\mathrm{S}-100$ protein levels as summarized in Figure 2 in different groups of leprosy sera ranged between 0.19 to $0.45 \mathrm{ng} / \mathrm{ml}$ compared to that of normal sera $(0.07 \mathrm{ng} / \mathrm{ml})$ and the difference was significant $(p<0.005)$.

Considering the mean \pm SD of S-100 protein levels in normal group as threshold value for positive reaction 5 of 7 indeterminate cases, 16 of 18 TT cases, 13 of 17 BT cases, 6 of 6 BL cases and 23 of 24 LL cases showed the presence of S-100 protein (Figure 3). 


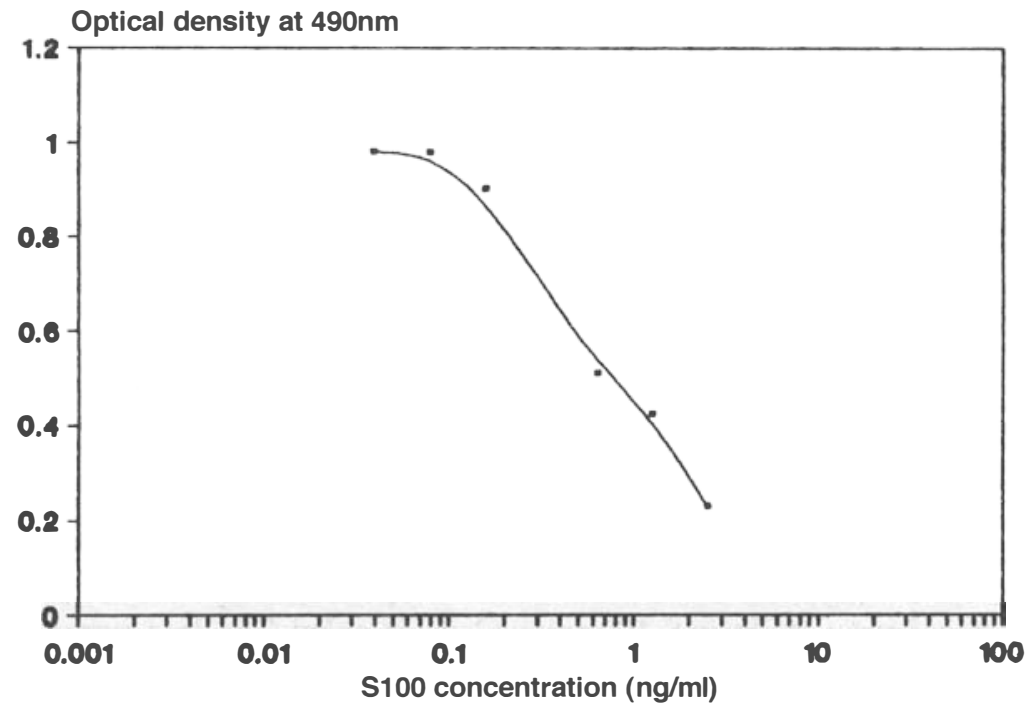

Figure 1. Calibration curve for S-100 using standard (S100a) concentration $(0 \cdot 4-2 \cdot 5 \mathrm{ng} / \mathrm{ml})$ by inhibition ELISA.

The results of analysis of sera samples for anticeramide $\operatorname{IgM}$ antibodies have been summarized in Figures 4 and 5. The mean OD values of anticeramide antibodies in different groups of leprosy sera varied between $0 \cdot 141$ and $0 \cdot 275$ compared with that of normal 0.063 and the difference was highly significant $(p<0 \cdot 0005)$.

By considering the mean \pm 2 SD of optical density shown by normal sera as threshold

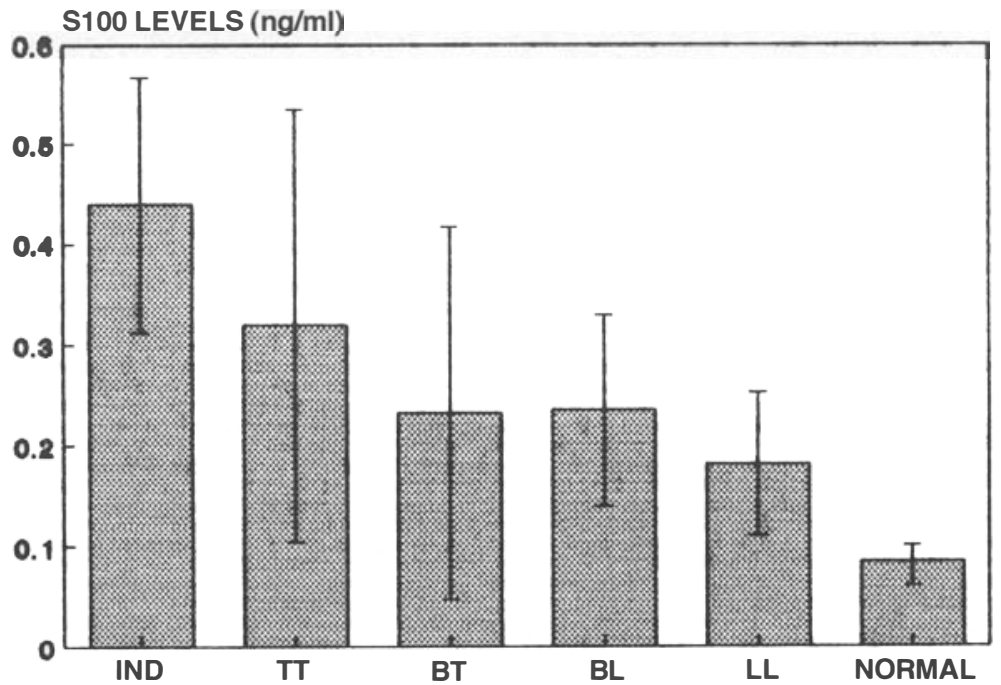

Figure 2. Mean \pm SD values of S-100 in sera of different groups of leprosy patients. 


\section{$\mathrm{S}-100 \mathrm{ng} / \mathrm{ml}$}

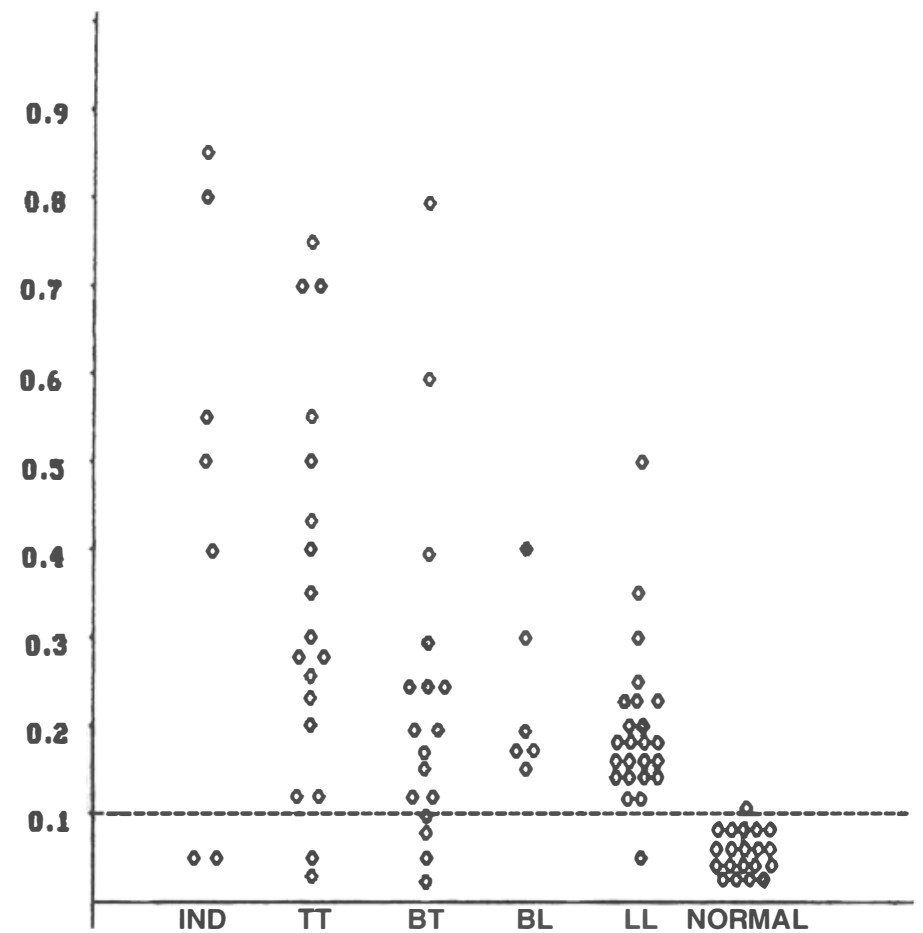

$\begin{array}{lllllll}\text { No. Positive } & 5 & 16 & 13 & 6 & 23 & 1 \\ \text { No. Screened } & -\frac{1}{7} & \frac{17}{18} & \frac{17}{17} & -\frac{1}{6} & \frac{24}{20}\end{array}$

Figure 3. Scattergram showing levels of S-100 in different categories of leprosy patients. Mean $\pm \mathrm{SD}=0 \cdot 1 \mathrm{ng} / \mathrm{ml}$.

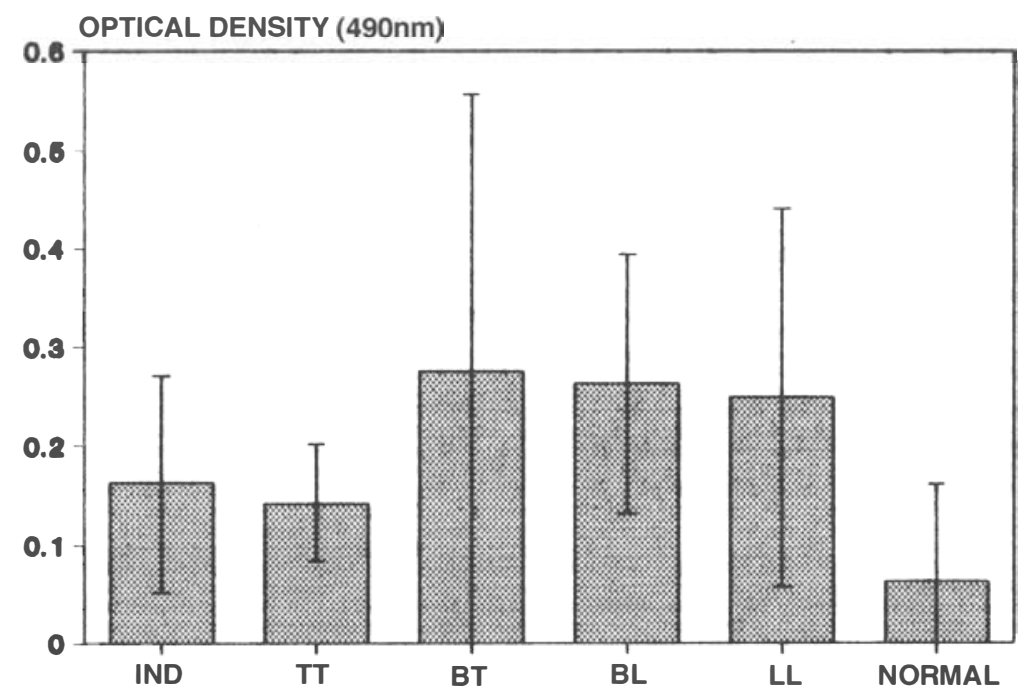

Figure 4. Anticeramide IgM reactivity of sera of different groups of leprosy patients. 


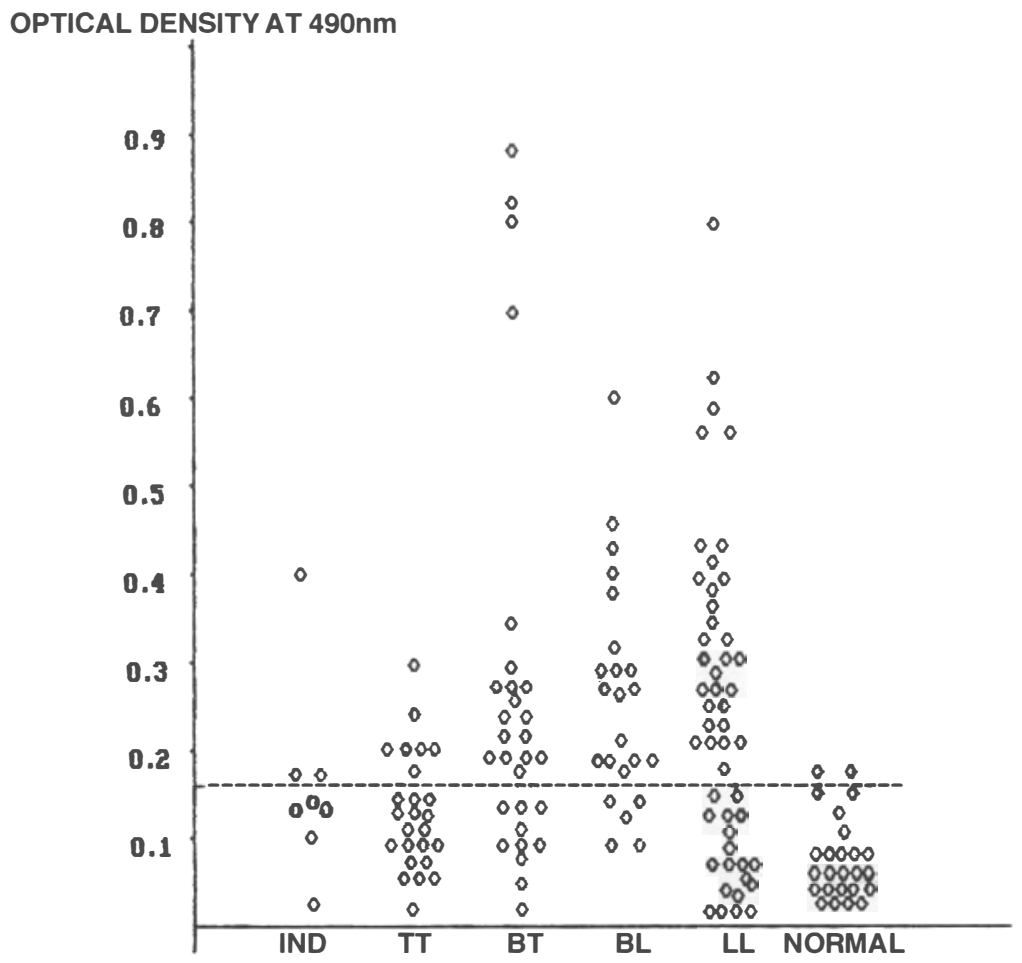

$\begin{array}{ccccccc}\text { No. Positive } & 3 & 7 & 19 & 18 & 31 & 2 \\ \text { No. Screened } & -8 & \frac{7}{25} & \frac{1}{29} & \frac{2}{23} & \frac{50}{50} & \frac{25}{25}\end{array}$

Figure 5. Antibody response (optical density) against ceramide in different groups of leprosy patients. Mean \pm 2 $\mathrm{SD}=0 \cdot 162$ of normal samples taken as cut off for positivity.

value for positive reaction, 3 of 8 indeterminate, 7 of 25 TT, 19 of $29 \mathrm{BT}, 18$ of $23 \mathrm{BL}$ and 31 of $50 \mathrm{LL}$ had detectable values of anticeramide antibodies.

\section{Discussion}

Leprosy being essentially a disease of the peripheral nerves, leads to nerve damage of varying extents in virtually all leprosy patients. Having no definite information on the exact cause of pathogenesis, the autoimmune response against nerve antigen is believed to be one of the possible events leading to nerve damage. The assay of S-100 protein as well as the anticeramide IgM antibody have been assessed as to how well they detect nerve damage in leprosy patients.

The results of the present study for anticeramide antibodies showed $37.5 \%$ indeterminate cases, $28 \% \mathrm{TT}, 66 \% \mathrm{BT}, 78 \% \mathrm{BL}$ and $62 \% \mathrm{LL}$ positive. The sera of borderline cases had higher levels of anticeramide antibodies (Mean \pm 2 SD; OD 0.222 $\pm 0 \cdot 220$ ) compared to the levels in tuberculoid group $(p=<0 \cdot 15)$. In a recent study anticeramide and antigalactocerebroside antibodies were found in sera of all categories of leprosy patients. Further, 
anticeramide antibody titres were found to be higher compared to the titres of antigalactocerebroside antibodies. ${ }^{10}$ Antigalactocerebroside antibodies have been shown to be a cause for demyelination. ${ }^{15,16}$ Antibodies to galactocerebroside and to nerve tissue preparations containing galactocerebroside have been found in patients suffering from multiple sclerosis and other demyelinating diseases. ${ }^{17,18}$ Antibodies against total nerve lipid were demonstrated in $50 \% \mathrm{TT}, 36 \% \mathrm{BT}, 50 \% \mathrm{BL}$ and $42 \% \mathrm{LL}$ as against galactocerebroside in $71 \% \mathrm{TT}, 71 \%$ BT, 33\% BL and 50\% LL cases. This could be due to a secondary effect as a release of otherwise sequestered myelin lipids that are recognized by the immune system. ${ }^{7}$ On immunoblotting, anti S-100 antibody and antiglial fibrillary acidic protein were found to react with antigen obtained from nerve sonicate. ${ }^{5}$

Analysis of the sera for S-100 antigen detection shows that while only 5\% of normals had higher S-100 protein, as many as $87.5 \%$ of different groups of leprosy patients show higher levels (Figure 2). Since S-100 protein is shown to be specific to nerve tissue ${ }^{19}$ higher circulating levels detected in a majority of leprosy patients, possibly indicate progressive destruction of peripheral nerves in these cases. In indeterminate groups 5 of 7 cases had higher levels of S-100 protein. It is possible that these 5 cases are suffering from silent neuritis, and hence had no history of extensive nerve involvement. Such cases could be rigorously followed for better management. High levels of S-100 protein were also observed in $83 \%$ of borderline cases, possibly as a result of reversal reaction, a common phenomenon seen in this group. S-100 is a calcium-binding protein believed to be specifically present in the nervous system. However, it has also been shown by immunoperoxidase staining, to be present in various carcinomas of neurogenic and nonneurogenic origin, and also in a limited number of normal cells. It has been speculated that the presence of S-100 in nonneural cells is due to the origin of these cell types from a common ancestor and migrate to different tissues during embryogenesis. ${ }^{11}$ Depletion of S-100 protein in peripheral nerves in a tuberculoid granuloma, were studied by immunoperoxidase staining. ${ }^{12,14}$ Further, Job et al. ${ }^{13}$ also showed the usefulness of S-100 staining to aid in histopathological diagnosis of tuberculoid leprosy lesions, and concluded that S-100 staining is a useful marker.

\section{Acknowledgments}

This work was supported by JBTDR Research Scheme of MGIMS, Sevagram. The authors are grateful to Dr Sushila Nayar for her keen interest and encouragement. One of the authors (R. Narayan) is grateful to Dr Rama Mukherjee, NII, New Delhi for training and guidance in standardizing anticeramide IgM ELISA.

\section{References}

${ }^{1}$ Benjamins JA, Callahan RE, Runft D, Gerras G, Lefford MJ. Anti neural antibodies in leprosy sera further characterization of the antigens. J Neuroimmunol, 1989; 21: 125-135.

2 Wright DJM, Hirst RA, Waters MFR. Neural autoantibodies in leprosy. Lepr Rev, 1975; 46: 157-169.

${ }^{3}$ Mshana RN, Harboe M, Stoner GM, Hughes RAC, Kadlubowski M, Belehu A. Immune responses to bovine neural antigens in leprosy patients I. Absence of antibodies to an isolated myelin protein. Int J Lepr, 1983; 51: 33-40.

${ }^{4}$ Eustis Turf EP, Ben jamins JA, Lefford MJ. Characterization of antineural antibodies in sera of leprosy patients. J Neuroimmunol, 1986; 10: 313-330.

5 Thomas BM, Mukherjee R. Antineural antibodies in sera of leprosy patients. Clin Immunol Immunopathol, 1990; 57: 420-429. 
${ }^{6}$ Rekha V Sahasrabudhe, Subhada R Dandekar, Damayanti H Shah, Subhada S Pandya, Ganapati R. Humoral response to nerve glycolipid antigen in sera of leprosy patients. Int J Lepr, 1992; 60: 488-490.

7 Nalini Vemuri, Rama Mukherjee. Immunoreactivity of nerve lipid antigens in leprosy. J Clin Lab Anal, 1991; 5: $157-161$.

8 Zeballos RS, Rox RI, Cheresh DA, McPherson RA. Antiglycosphingolipid autoantibodies in rheumatologic disorders. J Clin Lab Anal, 1994; 8: 378-384.

9 Sang Nae Cho, Bobby J Gormus, Keyu Xu, Rudolf P Bohm, Jr., Gerald P Walsh, Wayne M Meyers, Joo Deuk Kim. Serologic responses to nerve antigens in sooty mangaby monkeys with experimental leprosy. Int J Lepr, 1993; 61: 236-244.

10 Vemuri N, Viera LM, Taneja KK, Gangal SV, Mukherjee R. Antisphingolipid antibodies in the sera of leprosy patients. Lepr Rev, 1996; 67: 95-103.

11 Harriette J Kahn, Alexander Marks, Heather Thom, Reuben Baumal. Role of antibody to S-100 protein in diagnostic pathology. Am J Clin Path, 1983; 79: 341-347.

12 Raul N Fleury, Carlos E Bacchi. S-100 protein and Immunoperoxidase technique as aid in histopathologic diagnosis of leprosy. Int J Lepr, 1987; 55: 338-344.

${ }^{13}$ Charles K Job, Angelina T Deming, Robert C Hastings. Role of S100 protein as a marker for schwann cells in diagnosis of tuberculoid leprosy. Int J Lepr, 1990; 58: 392-393.

14 Navjeevan Singh, Arora VK, Ramam M, Tickoo SK, Bhatia A. An evaluation of the S-100 stain in the histological diagnosis of Tuberculoid leprosy and other granulomatous dermatosis. Int J Lepr, 1994; 62: 263-267.

15 Hruby S, Alvord EC, Seil FJ. Synthetic galactocerebrosides evoke myelination-inhibiting antibodies. Science, 1977; 195: 173-175.

${ }^{16}$ Fry JM, Weissbarth S, Lehrer GM, Bornstein MB. Cerebroside antibody inhibits sulfatide synthesis and myelination and demyelinates in cord tissue culture. Science, 1974; 183: 225-248.

17 Lisak RP, Heinze RG, Falk GA, Kies MW. Search for antiencephalatogen antibodies in human demyelirative diseases. Neurology, 1968; 14: 122-128.

18 Ruutiainen J, Reunanen M, Frey H. Galactocerebroside antibodies in multiple sclerosis. Acta Neurol Scand, 1982; 65 (Suppl 90) 260-261.

19 Moore BW. A soluble protein characteristic of the nervous system. Biochem Biophys Res Commun, 1965; 19: 739-744. 